\title{
Labour Market Analysis in the Central and Eastern European Countries
}

\author{
Amalia Cristescu ${ }^{1}$, Larisa Stanila ${ }^{2}$, Madalina Ecaterina Popescu ${ }^{3}$ \\ and Maria Denisa Vasilescu ${ }^{4}$ \\ ${ }^{1,3}$ Bucharest University of Economic Studies, Bucharest, Romania \\ ${ }^{1,2,3,4}$ National Scientific Research Institute for Labour and Social Protection, Bucharest, \\ Romania
}

Correspondence should be addressed to: Amalia Cristescu; cristescuamalia@gmail.com

Received date: 3 September 2013; Accepted date: 14 March 2014; Published date: 11 February 2015

Academic Editor: Andreea Claudia SERBAN

Copyright (C 2015. Amalia Cristescu, Larisa Stanila, Madalina Ecaterina Popescu and Maria Denisa Vasilescu . Distributed under Creative Commons CC-BY 4.0

\begin{abstract}
Over the last twenty years, Central and Eastern European countries (CEE) experienced a specific pattern of economic and social evolution. In the post-communism period these countries have initiated a comprehensive process of catching-up the capitalist economies. This process involved a series of institutional reforms and the liberalization and integration of some important markets (capital market, labor market, etc.). In these circumstances, the actual economic crisis represented a major challenge for these economies, which moreover were quite affected and the recovery is slow. For the purpose of the statistic data analysis, we decided to form two groups of countries, based on their history, background and recent development. We first made an analysis of the evolution of macroeconomic indicators to see how economic policy measures were favourable overcoming the crisis for each country. Using a panel date model, we aim to illustrate the influence of some important macroeconomics indicators (unemployment rate, GDP, FDI) on the labour market (real average net earnings, employment rate). The econometric results revealed that the GDP and FDI have a positive influence upon the two dependent variables, reflecting a normal economic situation.
\end{abstract}

Keywords: earnings, employment, economic crisis, panel data, Central and Eastern European countries

\section{Introduction}

In order to achieve the transition from the centralized planning to a market economy, the countries of Central and Eastern Europe (CEE) had to quickly adopt a wide range of reforms. As a result, these countries faced a strong recession after the collapse of the communist regime, though they were following a quick and easy process of catching up with the countries of Western Europe. This process was accompanied by the appreciation of the real exchange rates and the depreciation of the interest rates. 
The financial and economic crisis had a greater impact on the Central and Eastern European countries than on other countries of the world and the post-crisis recovery is also slower in these countries. Moreover, the consequences of the crisis on labour markets were simply devastating. As stated in the ILO Global Wage Report (2010), "unemployment has risen to 210 million people, the highest level ever, and several million people were simply excluded from the labour force because they were too discouraged to keep looking for a job. Wages were also affected."

Unlike developed countries where unemployment rose during the first stages of the crisis, developing countries with low or medium income were faced with much more serious problems throughout the crisis, because of the weaknesses in the social protection systems. Thus, they proved to present both a deterioration of the quality of the labour use and a decrease in wages, respectively a trend towards more vulnerable forms of employment.

Since they were very open to international trade and capital flows, the CEE countries became dependent on export and thus the decrease of the demand in the developed countries had a direct impact on their economies. Despite the fact that these countries did not have toxic assets in the banking system or other areas of the economy, the perception of the financial crisis was negative and thus even the CEE countries with robust economic governance were confronted with negative effects.

Because of the consumption and the real estate sectors growth which were supported by a dramatic increase in credit, the CEE countries have experienced current account deficits and great external debts and thus became vulnerable even before the crisis.

Despite the fact that prior to the crisis it was believed that those vulnerabilities will adjust themselves in the economic dynamics, the reality of the crisis proved to be harsh and required much faster and deeper adjustments than one might have anticipated. Thus, inflation exploded to the levels of two figures in Bulgaria, Estonia, Latvia and Lithuania between 2005 and
2008. Moreover, these countries lost their competitiveness because of the increase in wages and real estate prices, which undermined the current account balance. The onset of the financial crisis in 2008 represented a decrease in the macroeconomic output in the CEE countries and an increase in unemployment. Thus, three countries in the region - Latvia, Romania and Hungary - turned to the IMF for emergency programs. Bulgaria, Romania and Hungary, and especially the Baltic countries had to undertake radical fiscal adjustments. Many CEE countries have implemented anti-crisis programs, first by cutting public spending and by small tax increases. On the other hand, both the private and public sectors were faced with severe cuts in production costs, mainly through salary cuts, which led to significant reforms in public administration, health and education. These measures were accompanied by deregulations of labour markets.

According to an OECD report (2008), the foreign direct investment (FDI) is a vector of economic development due to technology, managerial know-how, access to new markets and new jobs creation. Therefore, the economic policies implemented in many developing countries have attempted to offer benefits to foreign investors. Thus, FDI flows have contributed greatly to the production of high quality goods and services, with a significant contribution to the national stock of capital and know-how. As for the impact of the FDI on labour markets, there seems to be a recurrent question: whether foreign companies pay higher wages and whether this contributes to the growth of the average wage in the host countries (Lipsey, Sjöholm, 2004). According to Lipsey (2004), the impact of the FDI on the average wage growth is explained both by the increase in labour demand and by the increase of higher wages in the average wage calculation structure. Beyond these advantages, foreign companies have been frequently accused of "grasping unfair advantages from the low wage level and the low standards of labour markets in developing countries." In conclusion, we can say that the low levels of wages attracted FDI which later contributed to wages 
growth. Furthermore, FDI flows contributed to the employment improvement by providing jobs in the host countries. While studying the contribution of FDI on employment in China, $\mathrm{Fu}$ and Balasubramanyam (2005) concluded that a $1 \%$ increase in the volume of FDI results in a $3 \%$ increase in the level of employment. Similar conclusions were also reached by Craigwell (2006) in a study conducted in the countries of the Caribbean, highlighting the positive role of FDI by means of technology transfer and the development of skills and knowledge among local managers.

The implications of wage levels on employment are very different. According to the assumptions of the neoclassical model, the labour market works perfectly if it is not disturbed by institutional impediments as employment and wages are inversely related. Such a relationship was revealed by studies conducted by Arestis and Mariscal (1994), Suedekum and Blien (2004) on the economies of Great Britain, Germany and Australia.

The Keynesian theory argues that changes in real wages do not affect the employment level. Although a decrease in wages leads to an increase in labour demand, there is no correlation mechanism of the employers' will to hire more people and the intentions of the unemployed to occupy the new jobs (Christopoulos, 2005). Therefore, there is no long-term relationship between real wages and employment. This result is contradicted by Apergis and Theodosiou (2008) who provided empirical evidence in favour of the long-term relationship between real wages and employment, and explained the failure of the short-term relationship by the fact that real wage cuts in the short term are not significant enough to lead to an increase in production and hence in employment.

By analyzing the relationship between employment and economic growth, Seyfried (2011) showed that the upward trend of the GDP has a significant positive impact on employment growth. Similar results were obtained by others as well: Boltho and Glyn (1995) showed that for the OECD countries the elasticity of employment with respect to economic growth is $0.5-0.6$, while Padalino and Vivarelli (1997) reported an employment intensity of about 0.5 with respect to economic growth.

Studies on the economies of Bulgaria, the Czech Republic, Estonia, Latvia, Lithuania, Poland, Romania, Slovakia, Slovenia and Hungary have revealed that the economic growth strategies implemented by these CEE countries prior to the crisis relied on foreign savings through three channels: FDI, crossborder loans and exports. Poland, the Czech Republic, Slovenia and Romania are the countries that recovered quicker as a result of adopting floating exchange rate regimes and a slight depreciation of national currencies. By contrast, the Baltic countries that have made efforts to maintain a balanced exchange rate and to avoid the devaluations of the currency, were faced with high levels of unemployment, low wages and increases in public debt (Kattel, 2010).

At the beginning of the crisis, the $10 \mathrm{CEE}$ countries were in a strong overheating phase of the economy, caused by an unsustainable credit expansion and an inflationary gap, with adverse consequences on the current account balance. However, Poland, the Czech Republic, Slovakia and Slovenia have not gone through individual crisis, but Hungary has experienced a series of problems for a long period of time because of the fiscal relief (Aslund, 2012).

For the purpose of the statistic data analysis, we decided to form two groups of countries, based on their history, background and recent development. Therefore, we will analyse the Central European EU members (CE5): the Czech Republic, Hungary, Poland, Slovakia and Slovenia and the Baltic and Balkan EU members (BB5): Bulgaria, Estonia, Latvia, Lithuania and Romania.

The countries in the first group (CE5) experienced an economic growth accompanied by a slight improvement in trade balances as a result of a reindustrialization process, a situation which is reflected in a reasonable balance of current accounts. 
In the same period, the Baltic and the Balkan countries (BB5) experienced continual deteriorations of trade balances and were characterized by rapid increases in external debts. Studies conducted by Becker et al., (2010) on this group of countries reported a rapid increase in real estate prices, an appreciation of the real exchange rate, accompanied by a significant decrease in real interest rates and an increase in inflation during the pre-crisis period. These elements suggest that the economic growth of this group of countries was rapid though unsustainably fuelled by a strong expansion of the credit system and by FDI flows directed to the banking and real estate sectors but also other sectors of the national economies (Becker et al. 2010).

\section{Methodology}

The econometric analysis underlined in this study relies on panel data estimation. A regression on panel data has the form: $y_{i t}=\alpha_{i}+x_{i t}{ }^{\prime} \times \beta+\varepsilon_{i t} \quad i=1 \ldots N, t=1 \ldots T$ , the $i$ subscript refers to the cross-section dimension and $t$ refers to the time dimension.

The individual effects may be either assumed to be correlated with the independent variables (the fixed effects model) or may be included into the residuals, assuming therefore that they are uncorrelated with the independent variables (the random effects model) (Baum, 2001).

For the fixed effects model, the most used estimator is the "within estimator", which applies ordinary least square on the model after mean-differencing. Because of this mean-differencing of the data, all timeinvariant variables will be zero and for this reason using such variable is not advised.
Because the fixed effects were removed (through mean-differencing), OLS results in consistent estimates of the coefficients.

A great advantage of panel data is the fact that it is possible to obtain consistent estimates even in the presence of endogenous regressors, because the $x_{i t}$ are correlated only with the $\alpha_{i}$, the timeinvariant component of the residual, not with the $\varepsilon_{i t}$ the time-varying component of the error.

The fixed effects model assumes that the error is independent and identically distributed, homoscedastic and not autocorrelated (Cameron and Trivedi, 2009). In the case of heteroskedasticity and/or autocorrelation, the errors will be biased and a robust estimation will be needed. In order to identify such problems, some authors have developed a number of tests (Drukker, 2003, Baum, 2001, Green, 2000) and also there are some procedures that correct the error structure.

\section{Data}

This study is based on the annual data for 10 Central and Eastern European countries, for the period 2000-2012 (for the econometric analysis the last year available for all variables is 2011). The variables used in the analysis are: the real average monthly net earnings in the prices of 2005 (EARN), the unemployment rate (UR), the real gross domestic product per capita as index with $2005=100$ (GDP), the foreign direct investment as percentage of GDP (FDI) (1) and the trade openness (TRADE). The sources of our data are the Eurostat and the UNCTAD online databases. 


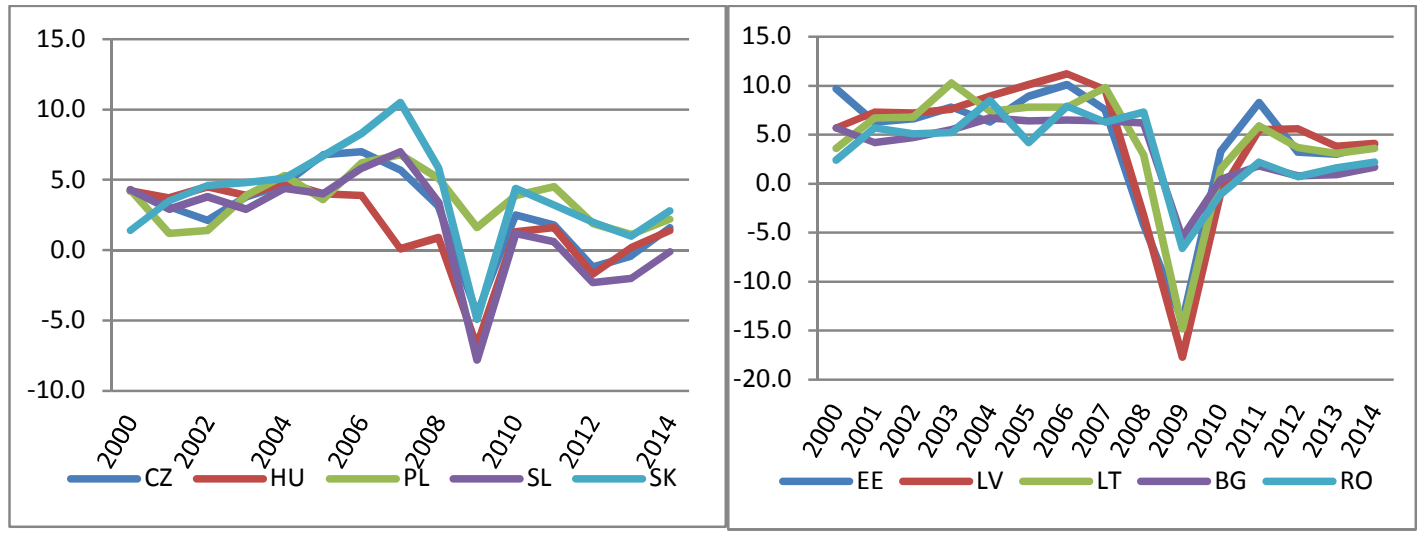

Data source: Eurostat

Figure1 : LReal GDP growth rate for the CE5

The economic downturn that erupted by the end of 2008 was over in 2010, when all CEE countries registered a slight economic growth. The entire region lost a few years of economic development, obviously a problem, but not a significant one considering the region's extraordinary growth rate in the period 2000-2008. From 2000 until 2008, all CEE economies experienced significantly higher growth. This growth performance was driven by important foreign capital inflows, especially from Western Europe and the technology transfer (by upgrading the product quality, improving the organisational structures and the functioning of the institutions, as well as the behavioural practices). This growth was
Figure. 2 Real GDP growth rate for the BB5

the main driver that enhanced the convergence process.

After the deep recession in 2009, all CEE countries experienced a slow recovery. In 2012, Hungary, Czech Republic and Slovenia experienced economic downturn because their economies were still affected by a weak domestic demand (fig.1). The domestic demand was the one that supported growth in Bulgaria, as well as in the Baltic countries (fig.2). In the actual international economic context, based on Eurostat predictions, the economic growth in the CEE countries is expected to have a modest increase $(2.3 \%$ in 2014).

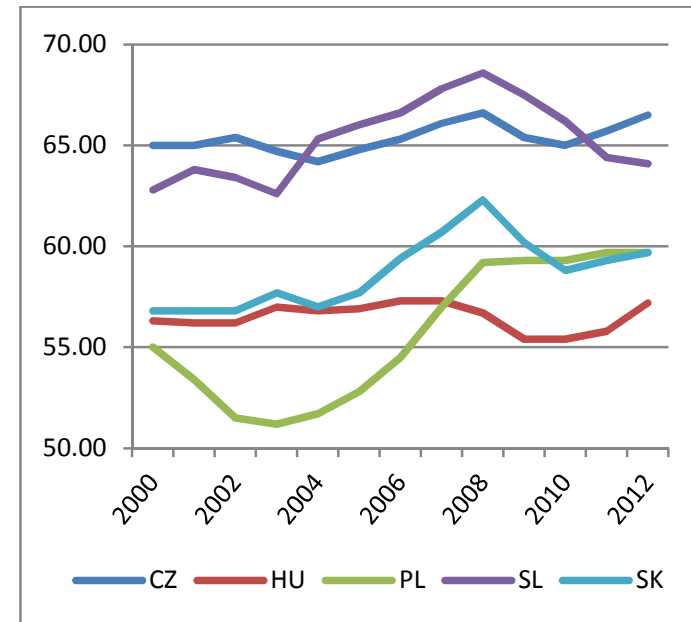

Data source: Eurostat

Figure: 3 Employment rate for the CE5

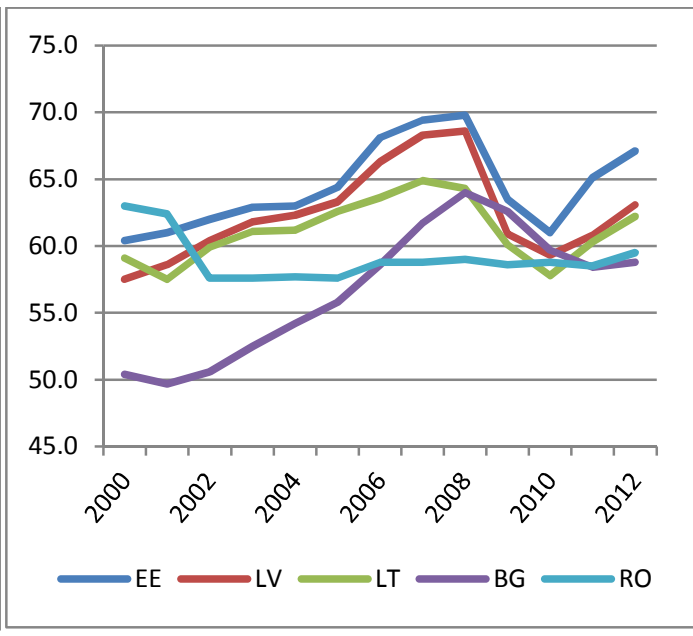

Figure: 4 Employment rate for the BB5 
The recent employment levels in the EU10 have risen above the minimum of the last three years, but they nevertheless remain below pre-crisis peaks. Despite higher overall growth rates in the EU10 region, employment during the crisis suffered more than in rest of Europe. It seems that the employers in EU10 were more prone to cutting employment than working hours.

In CE5, in the Czech Republic and Poland employment levels in 2012 were more close to the pre-crisis peak, helped by the economic growth that protects jobs. Slovenia and Slovakia had the slowest recovery in employment in the last two years.

In BB5, Estonia has improved most considerably over the past two years driven by strong economic rebound, which led to large job creation in manufacturing, construction and transportation. In Latvia and Lithuania, the employment level is still lower than the pre-crisis rate, reflecting large economic adjustment in the period 2008-2009. In Romania, employment rate has not recorded significant oscillations in the post-crisis period.

Before the economic crisis, the CEE labour markets had performed relatively well. Among CE5 countries (fig.3), only Poland and Slovakia had high rates of unemployment (over 10\%), while the other three countries had unemployment rates between 5\% and 10\%. During 2005-2008, unemployment had declined for all CEE countries. The decrease of the unemployment rate did not determine a significant inflation growth, meaning that the structural unemployment persisted. All BB5 countries experienced a decline in the unemployment rate during 2000-2008 (fig.4). The main causes of unemployment decrease were the creation of new jobs (economic growth) and the emigration of labour force in other EU countries.

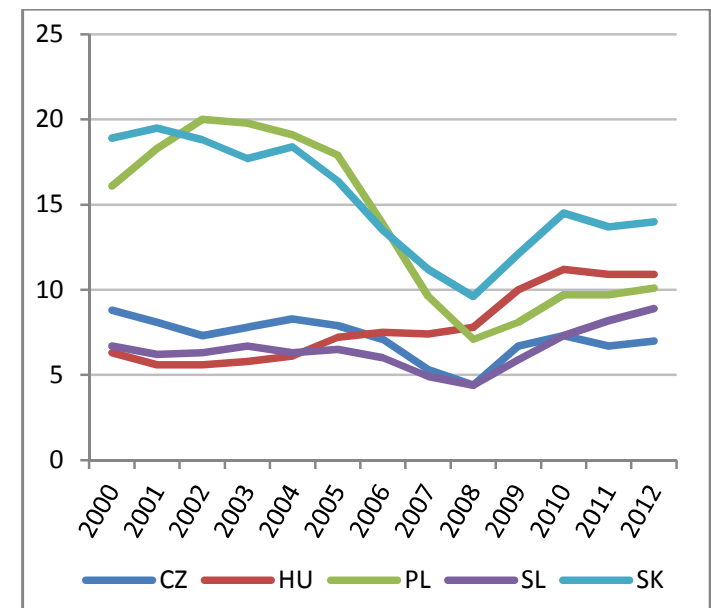

Data source: Eurostat

Figure 5: Unemployment rate for the CE5

In 2012, the unemployment rate still registered high values in the CEE countries. Slovenia (CE5) and Bulgaria (BB5) were the only two countries in the CEE region where, in 2012, unemployment reached a higher level compared with the period 2009-2010, when the economic crisis was at its peak. In Bulgaria, the unemployment rate was more than double compared to the pre-crisis period.

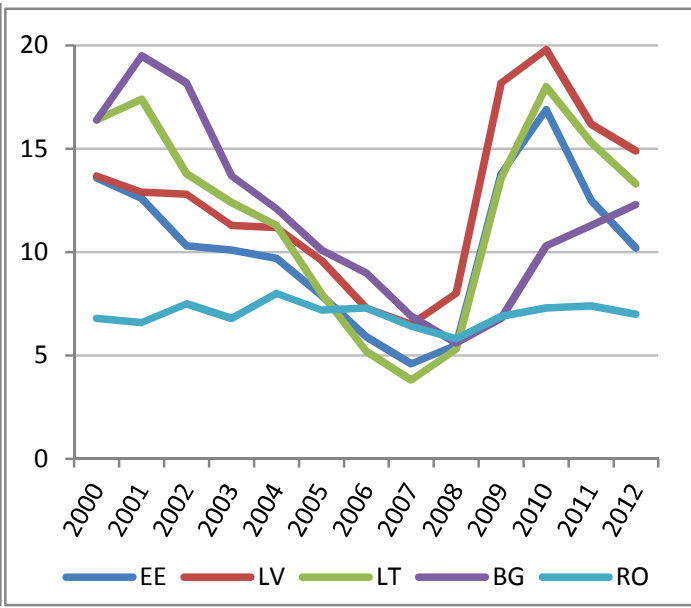

Figure6: Unemployment rate for the BB5

The poor labour market outcomes observed in the Czech Republic and Slovenia came from the persistent recession. In Bulgaria, employers had to adjust to lower demand by reducing the labour force as the wages were growing, mainly because of several increases of the minimum wage. In the other CEE countries, unemployment remained stable or even declined since the crisis reached its maximum. Romania seems to be the only country from BB5 that had an evolution of 
the unemployment rate without major fluctuations. Severe declines of the unemployment rate were noticed in Estonia, Lithuania and Latvia determined by the economic recovery and government policies (programs with EU funds).

In the last decade, the CEE economies attracted many FDI and should still be an attractive destination for FDI, especially if in these countries the business environment continues to improve. In 2009, FDI flows declined for all CEE countries, but especially in the Czech Republic, Hungary, Slovakia, Slovenia (CE5) (fig.5), Lithuania and Latvia (BB5). The collapse in FDI coincided with the credit crunch and economic recession. For the most CEE economies, FDI flows remained stable during the last two years. In Bulgaria, the highest growth of FDI was registered in 2007 (30\% in GDP) followed by a sharp decline during 2008-2010 (fig.6). Higher share of FDI in GDP in some CEE countries, during 2000-2007, reflected the smaller GDP in these countries (Slovakia (CE5), Bulgaria and Estonia (BB5)).

The focus point of the growth strategy was the financial integration at the international level. This integration was a major factor in sustaining the capital inflows, which took various forms, from foreign direct investment to bank lending as well as portfolio flows (Fabrizio et al., 2009).

It seems that FDI was higher in CEE countries where the income per capita is relatively higher, the labour costs in manufacturing are relatively lower and the investor risks are also lower. Some of the CEE countries will continue the privatization process in several economic sectors (industry, transport, banking, etc.) and this will lead to an increase of the FDI in the region.

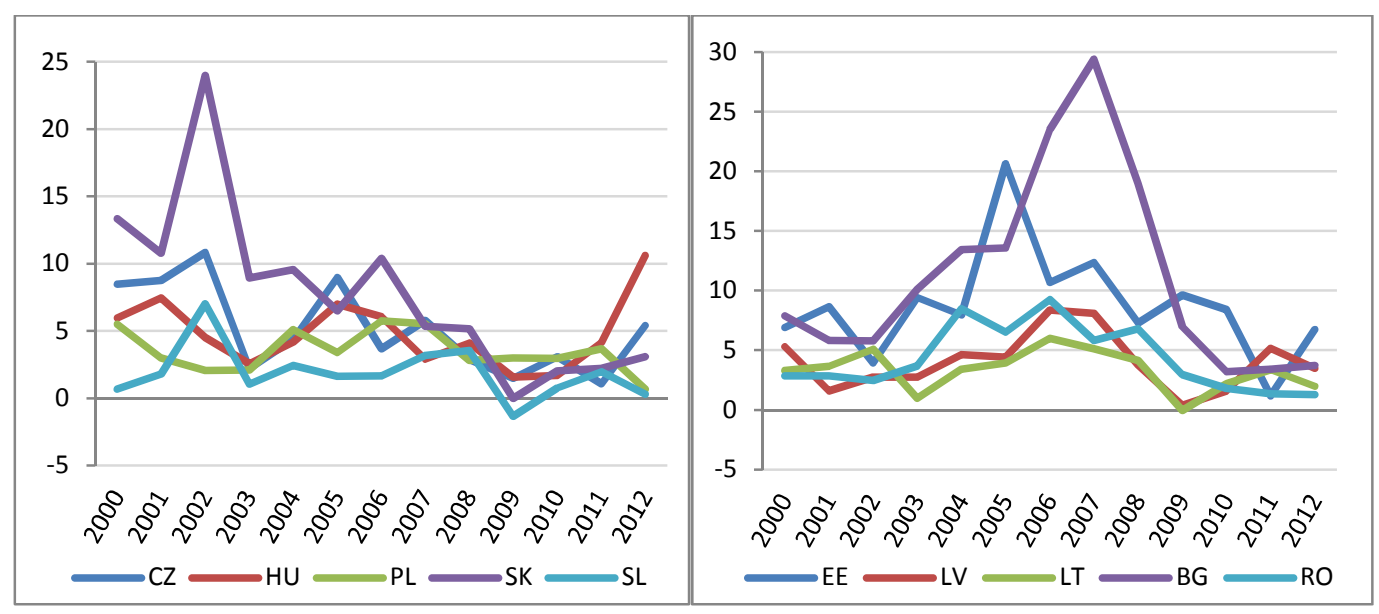

Data source: UNCTAD

Figure 7: FDI for the CE5 (\% for GDP)

Figure 8: FDI for the BB5 (\% for GDP)

It seems that FDI was higher in CEE countries where the income per capita is relatively higher, the labour costs in manufacturing are relatively lower and the investor risks are also lower. Some of the CEE countries will continue the privatization process in several economic sectors (industry, transport, banking, etc.) and this will lead to an increase of the FDI in the region.

Earnings are an important component of total consumption, a major factor in determining the economic performance of a country and also a standard of living indicator. During 2000-2007, earnings increased significantly in all CEE countries (fig. 9, fig. 10). The peak of this growth was 2008, the pre-crisis year. In many CEE countries, this increase was uncorrelated with labour productivity (especially in the public sector), primarily affecting economic competitiveness. In 2009, real monthly net earnings declined for all CEE countries, while in the period 2010-2012, real earnings registered a slight increase. Positive growth 
in real earnings during a financial crisis can sometimes be attributed simply to lower inflation and/or the concentration of job losses in low-paid jobs (ILO Report, 2010).

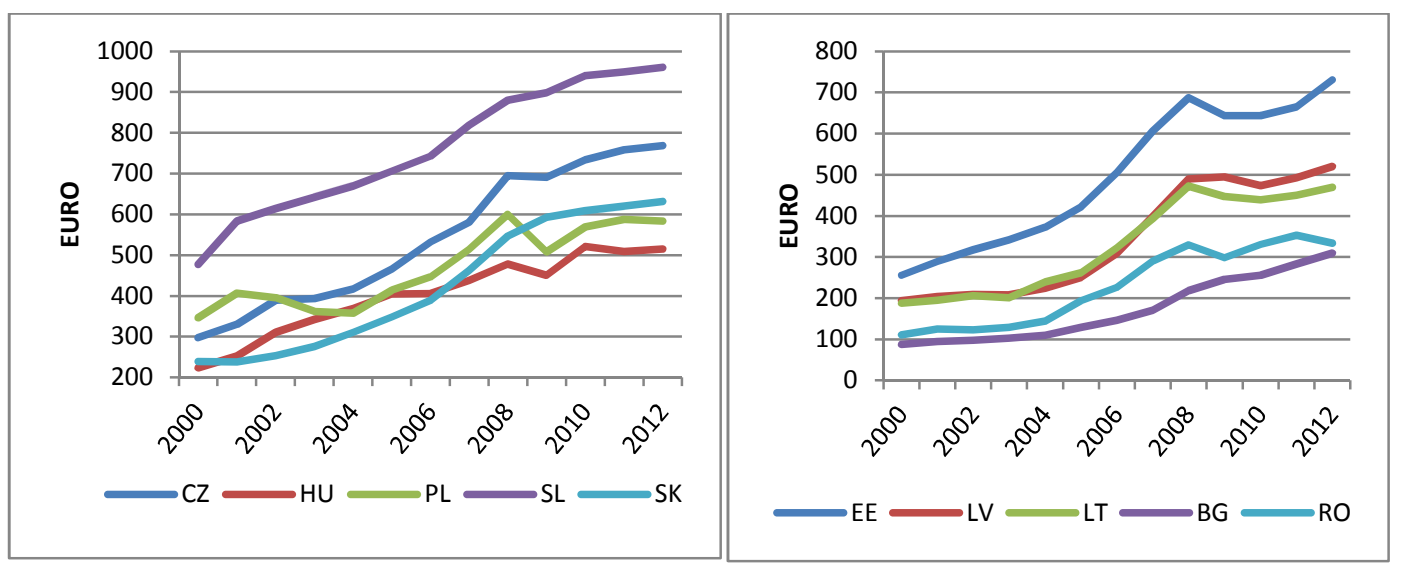

Data source: Eurostat

Fig. 9 Real average monthly net earnings for the CE5

\section{Economic Results}

We decided to use country fixed effects to control for time-invariant country specific unobservable effects. Moreover, we
Fig. 10 Real average monthly net earnings for the BB5 introduced FDI and GDP with a one year lag in order to take into account the adjustment lag between changes in these variables and their effects on labour markets.

The two equations have the following form:

$$
\begin{gathered}
E A R N_{i t}=c+\beta_{1} U R_{i t}+\beta_{2} G D P_{i t}+\beta_{3} F D I_{i t}+\varepsilon_{i t} \\
E M P L_{i t}=c+\beta_{1} E A R N_{i t}+\beta_{2} G D P_{i t}+\beta_{3} F D I_{i t}+\varepsilon_{i t}
\end{gathered}
$$

where:

$\mathrm{EARN}_{\mathrm{it}}$ - real average monthly net earnings for country $i$ and year $t$, in natural logarithm; $\mathrm{UR}_{\mathrm{it}}$ - unemployment rate for country $i$ and year $t$;

$\mathrm{GDP}_{\text {it }}$ - growth rate of real GDP for country $i$ and year $t$;

$$
\begin{aligned}
& \text { EARN }=3,91+0,02 * \mathrm{UR}+0,0073 * \mathrm{GDP}+0,0092 * \mathrm{GDP}(-1)+0,0026 * \text { FDI }(-1) \\
& {[41,6]^{*}[5,2]^{*} \quad[3,52]^{*} \quad[4,75]^{*} \quad[3,54]^{*}}
\end{aligned}
$$

where between brackets are the t-Statistics and * corresponds to $1 \%$ significance;

The estimation indicates that all variables have a positive, statistically significant impact on real earnings. The greatest influence on the net earnings comes from the unemployment rate, indicating that unemployment has primarily affected the lower-paid jobs (according to the economic theory which shows that the elasticity of
$\mathrm{FDI}_{\text {it }}$ - foreign direct investment as a percentage of GDP for country $i$ and year $t$; EMPL $_{\text {it }}$ - employment rate for country $i$ and year $t$

$\varepsilon$ - the residual error.

The earnings estimation results are presented below: labour demand is very high for the categories of less skilled workers). We could say that the personnel savings have enabled salary increases, or the effect of technological changes induced by foreign direct investment led to low-skilled workers reduction and the increase of highly skilled labour demand.

The influence of GDP is a normal one, in the sense that its growth, both in present and 
with a one year delay, has led to a growth in the labour demand (highly qualified workers) and therefore an increase in wages.

It is relevant to note the contribution of the GDP to the level of the average wage, not necessarily in terms of the sign or size of the coefficients, but in terms of the level difference favourable to the coefficient for lag 1 . This indicates a certain delay in the increase/decrease in wages, meaning a certain level of caution from the employers and resistance from the employees. In other words, the influence of the GDP still shows some rigidity on the labour markets of the new EU member states. From the employers' perspective, this caution is justified by the persistence of the crisis, while from the employees' perspective, the rigidity could be explained by low wage levels compared to the European average level.

FDI positively affects the average wage level, because the newly created jobs are better paid compared to the national level. The introduction of FDI with a one year lag shows that it takes time to manifest their effects. An inflow of FDI needs at least a year for the equipment to be installed and start to produce.

The fact that FDI has the slightest influence can be explained by a slower transmission of its effects, such as: changes in the labour demand structure in favour of better paid jobs, even if the effect of labour force saving appears.

The employment estimation results are presented below:

$$
\begin{aligned}
& \mathrm{EMPL}=80,34-6,955^{*} \mathrm{EARN}+0,197 * \mathrm{GDP}(-1)+0,042^{*} \mathrm{FDI}(-1) \\
& {[12,56]^{*} \quad[-5,28]^{*} \quad[9,23]^{*} \quad[4,57]^{*}}
\end{aligned}
$$

where between brackets are the t-Statistics and * corresponds to $1 \%$ significance;

Regarding the drivers of the employment rate, it is worth noting the high level of the coefficient associated to the average wage (6.955). As a sign, the correlation is normal, as it is consistent with the standard analytical form of labour demand. However, the high value of the coefficient of the equation reveals a relatively steep slope of the labour demand curve, meaning a great variation in labour productivity in terms of categories of labour supply and a high level of heterogeneity of labour supply.

The GDP influence is modest (0.196) as the improvement in the employment level involves more complex improvements in the functionality of the national economic system and not just a GDP growth. The positive sign of the coefficient is consistent with the economic theory and its location on lag 1 shows that it takes time for the macroeconomic dynamics to be reflected in the employment level.

The influence of FDI is positive as in equation 1 but the value of the coefficient (0.04 compared to 0.26$)$ shows that these investments do not significantly support the employment level but especially the wage level. In other words, it is possible that the new production capacities save labour force through modern technological contribution, but also create some new employment opportunities in the economic activities which are collateral and/or upstream the production chain. An additional argument is lag 1 on which the coefficient is located.

\section{Conclusion}

The development model for CEE countries was based on the political, financial and institutional integration with the EU. After the EU integration process, all the Central and Eastern European countries experienced significant labour mobility and institutional anchoring became a way to improve the process of building up economic institutions from scratch. Moreover, trade provided markets that lead to growth and to comparative advantage, while capital flows of the Western European countries towards the Central and Eastern European countries were justified by the deficits of modern equipment and infrastructure. The lack of management experience and technological backwardness were substituted by FDI and 
labour mobility limited the social cost of transition.

Based on GDP growth, inflation, current account balance, budget balance and public expenditures, the CEE countries, excepting

Hungary, succeeded in overcoming the macroeconomic crisis. The CEE region has now sound economic growth, although registering economic performances much lower than before the crisis. The current account is now reasonably close to balance, while budget deficits are moderate and set to fall even further. Hungary is the only exception, by having a public debt that exceeds the Maastricht limit of $60 \%$ of GDP, while most CEE countries have public debt of about $40 \%$ of GDP (Aslund, 2012).

The first estimation indicates that all variables have a positive, statistically significant impact on real earnings. The greatest influence on the net earnings comes from the unemployment rate. The influence of GDP is a normal one, in the sense that its growth leads to an increase in the highly qualified labour demand and therefore an increase in wages. The foreign direct investment was included in the econometric model with a one year lag, suggesting that it takes time to manifest their effects.

The results of the second estimation are consistent with the economic theory. The greatest influence on the employment rate comes from earnings, but this influence is negative. Both GDP and FDI exert their influence through the first lag, indicating that it takes time for the effects of these indicators to be felt on employment.

The econometric estimates show that the Central and Eastern European countries have functional labour markets which are a very important step in the establishment of the single European labour market. Thus, both the earnings and employment rates are normal correlated with other macroeconomic variables, in accordance with the modern economic theory, bringing additional support to the fact that, at least regarding the functioning of markets, the former socialist countries have completed the transition to a market economy.
Labour market conditions are not expected to improve by the end of 2014. Economic growth is likely to remain too sluggish to create enough jobs to reduce unemployment rates. New hiring may initially be limited to people with specific skills and the lowskilled, as entrepreneurs make use of existing government programs (labour subsidies) and flexible contract arrangements. Only when the sustainability of the economic recovery is more certain will unemployment rates be likely to fall significantly.

Because of the medium term economic uncertainty, the CEE countries need to pursue decisive economic policies. In order to accelerate their growth, the CEE should focus on a prudent macroeconomic policy that would shore up the confidence of financial markets. Structural barriers to economic activity need to be removed in order to achieve the medium-term economic growth potential. The key reforms for the CEE countries should therefore focus on incentives for labour mobility, more sustainable public finances, better adapted social security systems to demographic developments and harmonized regulations across borders.

\section{Endnotes}

(1) According to UNCTAD „foreign direct investment (FDI) is defined as an investment involving a long-term relationship and reflecting a lasting interest in and control by a resident entity in one economy (foreign direct investor or parent enterprise) of an enterprise resident in a different economy (FDI enterprise or affiliate enterprise or foreign affiliate). FDI includes the three following components: equity capital, reinvested earnings and intra-company loans. FDI flows with a negative sign indicate that at least one of the three components of FDI is negative and not offset by positive amounts of the remaining components. These are called reverse investment or disinvestment".

This work was supported from the European Social Fund through Sectorial Operational Programme Human Resources Development 2007-2013, project number 
POSDRU/159/1.5/S/134197, project title "Performance and Excellence in Postdoctoral Research in Romanian Economics Science Domain"

\section{References}

1. Aslund, A., (2012), „Lessons from Reforms in Central and Eastern Europe in the Wake of the Global Financial Crisis", The Peterson Institute for International Economics, Working Paper 12 - 7.

2. Baum, C. F., (2001), "Residual diagnostics for cross-section time series regression models", The Stata Journal, Vol. 1, pp. 101-104.

3. Becker, T., Daianu, D., Darvas, Z., Gligorov, V., Landesmann, M., Petrovic, P., Pisani-Ferry, J., Rosati, D.,Sapir A. and Weder Di Mauro, B., (2010), „Whither growth in central and eastern Europe? Policy lessons for an integrated Europe", Bruegel Blueprint Series, Volume XI, ISBN: 978-9-078910-17-6

http://www.wiiw.ac.at/modPubl/download. php?publ=ex1276602324

4. Boltho, A., Glyn, A. (1995), Can Macroeconomic Policies Raise Employment?, International Labour Review, Vol. 134, No. 4$5,451-470$

5. Cameron, A. C. and Trivedi, P. K., (2009), Microeconometrics Using Stata, Stata Press.

6. Craigwell, R. (2006) "Foreign Direct Investment and Employment in the English and Dutch-Speaking Caribbean", ILO Subregional Office for the Caribbean

7. Drukker, D. M., (2003), “Testing for serial correlation in linear panel-data models", The Stata Journal, Vol. 3, pp. 168177.

8. Fabrizio, S., Leigh, D. and Mody, A., (2009), „The Second Transition: Eastern Europe in Perspective", Economic Papers 366 available at http://ec.europa.eu/economy_finance/publi cations/publication14293_en.pdf
9. $\mathrm{Fu} \mathrm{X}$. and V.N. Balasubramanyam (2005), "Exports, Foreign Direct Investment and Employment: The Case of China" World Economy, Vol. 28, pp. 607-625

10. Greene, W.H., (2012), Econometric Analysis, Seventh Edition, Prentice Hall.

11. International Labour Organization (ILO), (2010), „Global Wage Report 2010/11: Wage policies in times of crisis", Geneva, International Labour Office, ISBN 978-92-2-123622-1 (pdf), available at http://www.ilo.org/wcmsp5/groups/public /@dgreports/@dcomm/@publ/documents/ publication/wcms_145265.pdf

12. Kattel, R., (2010), „Financial and Economic Crisis in Eastern Europe" available at

http://www.networkideas.org/featart/jan2 010/eastern_europe.pdf

13. Korczyc, E.; Laco, M.; Vincelette, G. A.; Madzarevic-Sujster, S. and Loichinger, E., (2013), "EU11 regular economic report : macroeconomic report - economic recovery on hold : special topic - determinants of job creation in EU11 : evidence from firm level data", Working Paper, Vol.1, report no. 78341, 2013

14. Lipsey, R. E. and Sjöholm, F., (2004), "Host Country Impacts Of Inward Fdi: Why Such Different Answers?", EIJS Working Paper Series 192, The European Institute of Japanese Studies.

15. Lipsey, R. E., (2004), "Home- and HostCountry Effects of Foreign Direct Investment", Chapter in NBER book Challenges to Globalization: Analyzing the Economics, Robert E. Baldwin and L. Alan Winters, editors (pp. 333 - 382)

16. Organisation for Economic Co-operation and Development (OECD), (2008), "The impact of foreign direct investment on wages and working conditions", Division for Employment Analysis and Policy, Directorate for Employment, Labour and Social Affairs, OECD-ILO CONFERENCE ON CORPORATE SOCIAL RESPONSIBILITY, Employment and Industrial Relations: Promoting Responsible Business Conduct in 
a Globalising Economy, OECD Conference Centre, Paris, France.

17. Padalino, Samanta, and Marco Vivarelli (1997). "The Employment Intensity of Economic Growth in the G-7 Countries,
International Labour Review 136 (2): 191213.

18. Seyfried, W. (2011) Examining the Relationship between Employment and Economic Growth in the Ten Largest States, Southwestern Economic Review, pp. 13-24. 